\title{
Correction to: You Can't Lose What You Haven't Got: Citizenship Acquisition and Loss in Africa
}

Bronwen Manby

\section{Correction to:}

Chapter 36 in: R. Bauböck (ed.), Debating Transformations of National Citizenship, IMISCOE Research Series, https://doi.org/10.1007/978-3-319-92719-0_36

The footnote given by the author was inadvertently missed in the previously published original version. The footnote is added as "* This text was written in November 2014 and reflects events current at that time. Some important later developments are not reflected, including, most importantly, the readmission of Morocco to the African Union in January 2017 and the decision of the African Court on Human and Peoples' Rights in the Anudo case against Tanzania issued in March 2018."

The author's request, during proofing, to add a footnote to the text, was unfortunately overlooked and is missing in the current text.

The updated online version of this chapter can be found at https://doi.org/10.1007/978-3-319-92719-0_36 